\title{
THE REVIEW OF THE LEGAL ASPECTS FOR THE DECLINING THE RISKS OF THE IT-PRODUCTIONS INTELLECTUAL PROPERTY RIGHTS INFRINGEMENT
}

Information technology is the object of fair and unfair competition both in the world and in Ukraine, especially due to the existence of the Internet. Therefore, it is necessary to regulate the relations between manufacturers and consumers of IT-technologies related to entrepreneurial activity, with the volume of digital products. This became the reason for the necessary influence on the legal regulation of consumer relations on the Internet.

The article analyzes the issue of choosing legal instruments for the protection of rights to information products, depending on how they are further used for further benefit from their use and eliminating the possibility of violating the rights of unscrupulous competitors.

The purpose of the article is to study the possibilities of protecting the rights to information technology as an object of intellectual property in order to eliminate the risks of violation of rights to this object. To achieve this, you must accomplish the following tasks: to consider the prevention processes of the intellectual property rights infringements of the information products using the existing legal tools; to analyze the components of information products in order to determine the optimal ways of their legal protection; to provide analysis of the information products legal protection using only copyright tools; to study the experience of the countries - leading information technologies manufacturers and users and to assess the possibility of the using this experience within the legal framework of Ukrainian legislation.

Methods: system analysis, comparative analysis.

Results. To determine the information technologies definition as a specific technologies that make enable to accumulate, process, store and transmit any received from the external environment information to the computer. IT-technologies are inextricably linked with the use of software and hardware complexes consisting of personal computers, mobile phones, communicators or workstations with the necessary set of peripheral devices equipped with the necessary software tools. These objects may be protected by patent law. The main recommendations for the infringements risks prevention were highlighted and the patentability frames of reference were proposed using the information products components identification. Conclusions. The article analyzes the issue of choosing legal instruments for the protection of rights to information products, depending on how they are further used for further benefit from their use and eliminating the possibility of violating the rights of unscrupulous competitors. It is recommended to consider information products as a complex object, which must have versatile protection through copyright and patent rights.

Copyright protection does not protect software developers from encroachment on their IT-technology, but it contributes to other important result - improving the image of the organization and getting a positive goodwill. Patent law is most beneficial to protect software algorithms. The commercial secrecy is appropriate the IT-technology protection when it concerns the state security, military equipment est.

Key words: information technologies, computer programs, protection of rights, objects of intellectual property. 


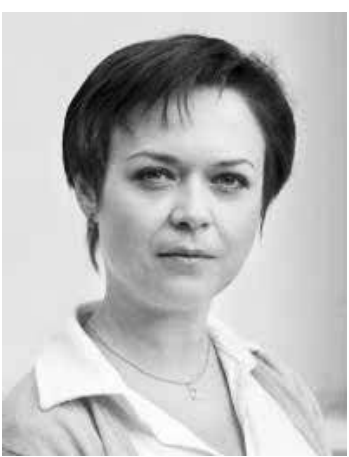

Natalia Rulykova,

Associate Professor of the Department of Intellectual Property and Project Management of the National Metallurgical Academy of Ukraine,

Candidate of Technical

Sciences

orcid.org/0000-0002-8383-8727 djonatanrulikov@gmail.com

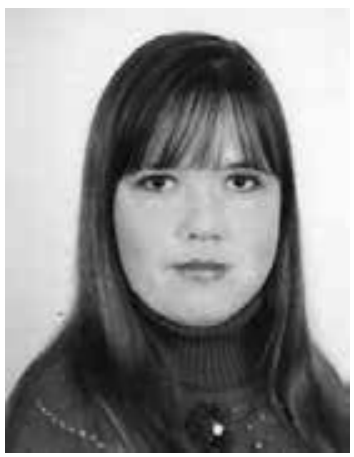

Yevgeniya Shvets, Assistant of the Department of Intellectual Property and Project Management of the National Metallurgical Academy of Ukraine orcid.org/0000-0001-7396-6744 belikovaevg@ukr.net

\section{Introduction}

Information technology has undergone such a global spread that it is already hard to imagine human life without them. At the present stage, it is possible to give examples of the use of information technologies in all areas, from education to business, without any difficulty. The greatest success will be with a firm, organization or enterprise with stateof-the-art computer technology, therefore, new information technologies are rapidly developing and constantly being refined. Programmers bring the national economy incomes calculated in billions of dollars, and therefore there is a huge amount of IT-orders.

In the society, computer technology has taken top of the leadership in technology. The software should be in any computer and laptop for normal operation. The protection and security of software as an intellectual property object is one of the most important in the field of software, as well as in other economic areas.

The study of relations in the field of information technology between producers and consumers was considered by K.V. Yefremova, Ye.P. Litvinov, O.O. Barabash, O.P. Buynitskaya, O.M. Tomashevsky, G.G. Tsehelik and others.

\section{Research results}

Hideyasu Sasaki highlighted that in the advent of multimedia digital libraries, the protection of their rights as intellectual properties is an urgent issue to offer an instrument for recouping investment in their development (Hideyasu Sasaki).

Public relations that arise on the Internet are extremely broad in scope and part of them can be regulated by existing legislative acts (for example, for combating criminal offenses, sufficiently current legislation, and some require special legal regulation (there is an urgent need for legal regulation in the sphere e-business and all its types) (Yefremova, 2014).

Any issues that have impact from any Internet subjects can be presented as the objects of Internet relationships.

Depending on the nature and types of Internet relationships, as the objects can be act: information services and their results, products of creative activity, including works of literature, art, music, etc., securities, contracts, official documents, honor, dignity, human security and others values. Hardware is the most important component of Internet relationships. They include a global pool of computer networks (regional, reference, departmental, corporate, local) and information resources (sites, e-mail services, search engines) (Barabash, 2018). 
Technology (from Greek) means art, skill. In the general sense, technology is a set of methods, means, and people's implementation of a particular complex process by dividing it into a system of successive interrelated procedures and operations that are used more or less unambiguously and aim to achieve the high efficiency of a particular type of activity.

Information technology is a set of methods, tools and techniques used to ensure the effective performance of people in various industrial and non-productive spheres.

On the basis of personal computers (computers), computer networks (systems of distributed data processing, consisting of computers connected by one's links (channels) of data transmission) and communication means, information technologies form information-communication technologies, the means of which are software and hardware (devices and electronic circuits-hardware, programs designed to work with the computer-software) and devices that operate on the basis of computer technology, as well as modern tools and systems of exchange, which provide opera ted for searching, collecting, collection, storage, processing, presentation, transmission of various kinds of data. These include computers, computer networks; means and devices for manipulating audiovisual data (based on multimedia technology and virtual reality systems); modern communication facilities; artificial intelligence systems; system of machine graphics; software complexes (Buinytska, 2012).

Information technology is a set of processes that use means and methods of accumulation, processing and transmission of primary information to obtain information of a new quality about the state of the object, process or phenomenon. This new quality information is called an information product - documented information that has been prepared and designed to meet the needs of users. Information technology as a system has the following properties: expediency; the presence of components and structure; interaction with the environment; integrity; time development (Tomashevskyi et al., 2012).

After analyzing all of the above definitions, the authors understand information technology as specific technologies that enable the computer to accumulate, process, store and transmit any information received from the environment. IT-technologies are inextricably linked with the use of software and hardware complexes consisting of personal computers, mobile phones, communicators or workstations with the necessary set of peripheral devices equipped with the necessary software tools.

The subjects of legal relations in the field of information technology can be network designers; customers are users; communication operators; service providers that provide access to the Network; hosting providers that have disk space on their server for clients, as well as other basic Internet services; developers of cross-border information networks and network technologies; professionals who own rights and responsibilities in the virtual space of the Internet.

Subjects can act as legal entities (providers that have licenses for providing online services, as well as those providers who purchase Internet traffic from licensed operators), the individuals (citizens-consumers of information: Ukrainian citizens, foreigners, stateless persons, etc.). Moreover, these persons must comply with the requirements of international and national legislation in terms of legal capacity and capacity (Lytvynov, 2013). 
According to the legislation of Ukraine, the owner of information technologies, information systems, technologies and means of their provision in full implements the authority to own, use, and dispose of the specified objects.

The user (consumer) of information technologies refers to the information system or the intermediary for obtaining the information technology he needs and uses it. It is at this stage that possible cases of misuse of information technology. Therefore, it is important to have a reliable system of protection in this area both from the state side (creation of the regulatory-legislative base) and from the side of the owner of the technology (copy protection, codes, ciphers, cryptographic envelopes, limited functionality, etc.).

The most developed system of legislation in this area in the United States and in European countries. In this country, legislation was created consistently, as appropriate issues arise. Their total number is several hundred. No less intensive work is being done in this direction.

For Eastern European countries there is a significant lag in the field of legal regulation of information relations. Misunderstanding of the importance of these problems has affected the fact that national legislations did not actively organize and carry out legislative work in this area.

In Ukraine, the main legislative acts in the area of protection of the rights of developers and holders of IT-technologies and in general of all subjects of intellectual property rights are: the Constitution of Ukraine, the Civil Code of Ukraine, the Commercial Code of Ukraine, the Laws of Ukraine: "On Copyright and Related Rights", "On Protection of Rights to Industrial Designs", "On Protection of Rights to Inventions and Utility Models", "On Protection of Rights to Integrated Circuits' Topographies", "On the Protection of Rights to Trademarks for Goods and Services", as well as a number of sub-legal normative and legal acts detailing the provisions enshrined in the above-mentioned documents. The international legal acts, ratified by Ukraine in the field of protection and protection of rights to IT-technologies, are the Berne Convention for the Protection of Literary and Artistic Works, the Hague Agreement on the International Registration of Industrial Designs, the Paris Convention for the Protection of Industrial Property, and the TRIPS Agreement.

Today, the basic law "On Information" is in effect, several laws have been adopted, which can be attributed to special ones in this area - "On State Statistics", "On Scientific and Technical Information", "On National Archival Fond and Archival Institutions", "On State Secrets", "On information protection in automated systems" and others.

Some norms in this area are enshrined in the legislative acts: "On Operational Investigative Activity", "On the Security Service of Ukraine", "On Notary", "On the Bar", "On Civil Defense of Ukraine", "On the Organizational and Legal Foundations of Combating organized crime", "On Information Protection in Information and Telecommunication Systems", "On the Fundamentals of National Security of Ukraine" and a number of other normative and legal and subordinate acts.

Mostly, IT-products are computer software, website, database. Thus it was found that the criteria of patentability of IT technology are novelty, inventory level, technical result and safety.

A computer program consists of a certain source code and object code, which is represented as the original set of characters. The code of a computer program is unique, 
written by a person, that is, an author, and is considered the result of her creative activity. In this way, we see that first of all, from the creation of a computer program, copyright arises. Indeed, in most countries of the world, including in Ukraine, a computer program (software) as an integral part of information technology is protected by copyright (Selivanov, 2002).

In Ukraine there are three valid ways to protect a software product (program, website, database, etc.) from unlawful use:

- protection of the source code of the program and the protection of the title of the program by copyright;

- protection of the algorithms used in the program as a means of solving specific problems - the right industrial property.

Art. 437 CCU reports that copyright to a computer program has arisen since the creation of the computer program itself and does not require registration, special registration or compliance with any other formalities in relation to a computer program for the recognition of copyright in it. Art. $433 \mathrm{CCU}$ calls computer programs one of the objects of copyright and informs that computer programs are subject to the legal regime for the protection of literary works.

However, most copyrighters prefer to register their rights in the state register, since this gives a number of undeniable advantages:

- in Ukraine there is a presumption of authorship, according to which the author is considered to be the person indicated as the author on the original or a copy of the work, in the event that the opposite is not proved (Article 11 of the Law "On Copyright and Related Rights"). Certificate of registration of copyright is a reliable argument in the dispute for the right to own a software product;

- the presence of a certificate allows you to freely dispose of your rights to the program, database, or other work and delegate them to third parties. In order to obtain commercial returns, as a rule, are authors' agreements, and as an obligatory supplement to them, the author's certificate (copyright registration certificate), which certifies the rights of the author for what he is selling, serves as a compulsory supplement (Reiestratsiia prohram...).

Today, copyright registration for a program or database in Ukraine is one of the cheapest ways to protect rights.

Obtaining state security for software products and reliable proof of authorship can be done very quickly, following the standard copyright registration procedure.

According to Art. 435 The Civil Code of Ukraine (CCU), the primary subject, to which the copyright belongs, is the author of the computer program, the individual who created his program of creative work. In addition, the subjects of copyright may be other natural or legal persons who have acquired rights to a computer program on the basis of the contract or in accordance with the rules of law. Personal non-proprietary rights of authors (the right to name, the right to prohibit its use, the right to a pseudonym and the integrity of the work) are closely related to the person, and therefore they are inalienable (Article $438 \mathrm{CCU}$ ).

According to Art. $440 \mathrm{CCU}$ proprietary rights of intellectual property to a computer program is the right to use a work (right to publish, reproduction in any way and in any 
form, translation, processing, adaptation and other similar changes, inclusion in the constituent part in collections, databases data, etc., sale, transfer to hire (lease), import of his samples, samples of his translations, alterations, etc.), the exclusive right to authorize the use of works by other persons and the right to prevent the misuse of the work, including the prohibition of such using. These rights may be transferred to another person in whole or in part under the terms and conditions stipulated by the agreement on the disposal of intellectual property rights.

The main component of the essence of the program and the principles of its operation is the availability of source code, it is he who has the greatest value. Knowing it, you can improve and modify the program, as well as do reciprocal actions.

According to the Law "On Copyright and Related Rights", the computer program is protected only as a literary work, and methods of implementing the idea and functioning are not protected: " $<\ldots$. $>$ the legal protection extends only to the form of expression of the work and does not apply to any ideas, theories, principles, methods, procedures, processes, systems, methods, concepts, discoveries, even if they are expressed, described, explained, illustrated in the work". The legal regime for the protection of literary works can only protect the following elements of a computer program: source code, algorithm, music components, video files, characters and images used in computer programs. Very often copyright is violated precisely on these structural elements of a computer program or on the interface of the program. Thus, by changing, for example, the execution of the program, but without changing its essence, you can get a completely new object of protection. Unlike a work of art, the text of which can be used independently, the code of the computer program is worthless without the possibility of using it on a computer. Thus, comparing a computer program with an artistic product is inappropriate.

It was decided to protect the program interface as an industrial design, thus preventing it from being repeated by competitors. But such protection is also not enough, as it also does not apply to the protection of the concept of software.

The computer program functions not only with the source code, but also for the most part due to a certain method, means, algorithm of actions that can be the object of industrial property.

Today there is an interesting trend. As soon as a high-quality consumer product appears on the market, it immediately runs the risk of being copied, both in full and in parts. As a result the consumer, who was misled, is using scammer's productions, and the copyrighter once and forever is losing his client, who is dissatisfied with the faulty product.

In cases where it is important to protect the name of the program, its object code, and not the concept contained in the algorithm, it is expedient to register it and obtain a copyright certificate. Such registration does not require significant time and financial costs.

The protection of software or any application with a sign for notification is practically non-binding. The option of protection by technical means is not practical and applies only locally.

The protection of computer software by industrial property is not as known as copyright protection, and is used only in some countries. Improving the legal protection of computer technology was the first country interested in the rapidly expanding sphere of innovative information technology. The list includes EU, US, China, Japan, 
etc. Among the developers of computer programs, increased concern about the level of intellectual property protection needed to store and further develop innovative activity in the computer industry. Realizing that the computer industry is an area where significant financial resources can be created, a number of computer companies have begun active activities in the development of computer programs. These companies were interested in reliable protection of their products, because the creation of new programs required the investment of significant resources of a competing computer program using the idea of the existing. When conducting a qualification examination, a patented non-application, but a system, with the condition that it is claimed together with the hardware to be used. This is the opinion of not only the US, but also allows software patents in Japan, China, the UK and other EU countries under such conditions (Bazilevich, Ilin, 2010). Comparison of the security system of IT-technologies in Ukraine and the USA is presented in Figure 1.

The advantage of patent protection for computer programs is the ability to protect a particular algorithm embodied in a computer program from using it by others without permission. Instead, copyright offers significantly narrower possibilities, protecting only the "expression" of ideas and leaving the very idea of the program beyond the bounds of protection.

It should be noted that after obtaining a product in the process of development, it is expedient for IT manufacturers to understand which objects of intellectual property have their new development (objects of industrial property rights or copyrights) and in what quantity.

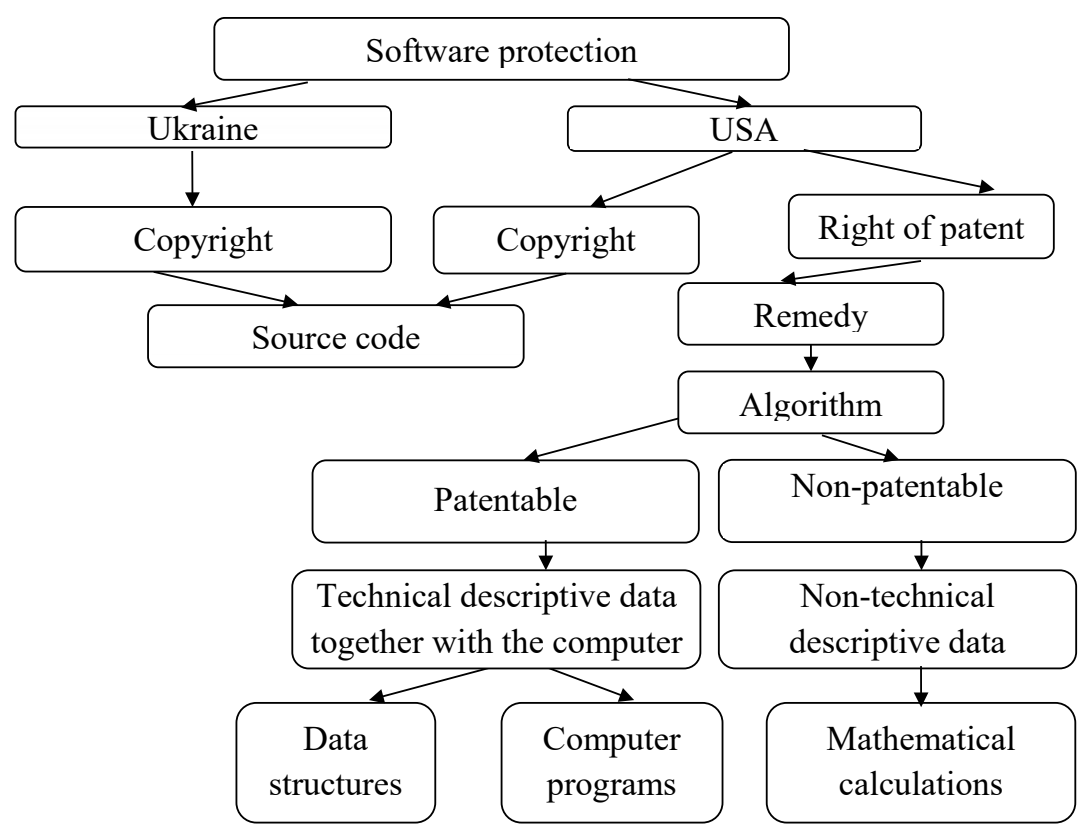

Fig. 1. Comparison of the security system of IT-technologies in Ukraine and the USA 
When selecting those or other objects it is important to remember that patent law can protect the algorithm and concept of the program, and copyright is only a form of expression of IT-technology. At the next step, you need to understand the purpose of using the product developed - for your own use or for transferring rights under a license agreement.

When setting up the accounting for rights to intellectual property objects, the value of the assets of an enterprise increases, that is, there is added value, which results in the law of value added tax, but this can be avoided legitimately if the employee of the enterprise will create IT-technology on an initiative basis, and not for an official task, and then pass it on to the enterprise under copyright or licensing agreements as an individual.

When assigning rights to an object of intellectual property rights in the authorized capital on the rights of operational management, the owner of the object of intellectual property right is entitled to delete the said objects that are not used, or those that are not used for purpose. At the core of this strategy is the understanding of the main principle, legal protection should bring greater advantage than the cost of acquiring rights.

Another option for protecting the rights to IT-technology, which is also aimed at monopolizing the right, is a commercial secret.

Commercial secrecy plays an important role in ensuring the competitiveness of goods and services. Therefore, the right holder, of course, has the right to protect it from unlawful use. It should be borne in mind that undisclosed information may be subject to legal protection as long as it retains its confidentiality. A more reliable way of protecting such information may be the application of measures that guarantee the preservation of its confidentiality, which in particular, may be protected by the contract (Tsybulov, 2003).

In this way, we can understand that copyright protection does not protect software developers from encroachment on their IT-technology, but it contributes to a different result - improving the image of the organization and getting a positive goodwill.

The most beneficial way to get a positive goodwill for developer organizations is to allow them to freely use their IT-technology. This tool is not economically viable, but it contributes to the marketing development of the reputation of the developer companies.

The choice of legal protection depends on the type of IT-technology and its cost. According to the evaluation of the selected IT-technology, the graphical user interface, it can be concluded that the development of these IT-technologies requires considerable effort and a lot of financial resources. It becomes clear that copyright protection and free use in this case will be totally disadvantageous for the company of IT developers, since both options do not provide for an increase in capital and a steady profit.

The protection of the graphic touch interface with the provisions on commercial secrets is also not entirely appropriate because the IT market and software, unlike other technologies, are rapidly becoming obsolete and supplanted by new developments. In our view, the protection of IT-technology in the form of commercial secrecy is appropriate when it concerns state security, military equipment, is the only one of its kind, and so on.

Thus, by the exclusion method for the protection of the selected IT-technology, namely the graphical user interface, the industrial property protection patent remains the most advantageous way. The claimed graphical user interface is a software program without 
which a new tablet or smartphone will not be able to work correctly and perform all the options embodied in the present invention. With this in mind, we can conclude that the graphical user interface is patentable software, because it is new, has a tangible technical result, is original and safe. It is advisable for the developer of this graphic user interface to recommend in its management strategy, which includes a strategy of protection in the formation of a portfolio to apply for a patent to the graphical user interface as a method.

\section{Conclusions}

After analyzing the legal basis of IT-technologies protection and the dynamics of its development, identifying the trends of the global and national IT market, offering and studying in detail the model of the strategy of protection of the rights of developers and users of IT-technologies, we can highlight several recommendations aimed at improving the situation of developers and users of IT-technologies in the economic space within the bounds of fair competition: when developing a new IT-technology, the company-developer must first clearly classify the created object of IT-technology in order to isolate the potentially protective elements of the IP; when patenting any object of intellectual property created in the IT-industry it is advisable to take into account the experience of other countries; in order to better assess IT-technology, it is necessary to analyze in detail its patentable components.

\section{Bibliography:}

1. Hideyasu Sasaki. Intellectual Property Protection for Multimedia Information Technology. URL: https://www.igi-global.com/book/intellectual-property-protection-multimedia-information/618.

2. Єфремова К.В. До перспектив правового регулювання інтернет-правовідносин: господарсько-правовий аспект. Право та інноваційне суспільство. 2014. № 1. С. 5-11.

3. Барабаш О.О. Загальна характеристика інтернет-правовідносин. IT-право: проблеми і перспективи розвитку в Україні: матеріали конференції. URL: http:/aphd.ua/ publication-183/.

4. Буйницька О.П. Інформаційні технології та технічні засоби навчання: навч. посібник. К.: Центр учбової літератури, 2012. 240 с.

5. Томашевський О.М., Цегелик Г.Г., Вітер М.Б., Дубук В.І. Інформаційні технології та моделювання бізнес-процесів: навч. посібник. К.: Центр учбової літератури, 2012. 296 с.

6. Литвинов Є.П. Правовідносини в інтернет-праві. Часопис Київського університету права. 2013. № 3. С. 145-149.

7. Селіванов М.В. Захист права на комп'ютерну програму (авторсько-правовий аспект): автореф. дис. ... канд. юрид. наук: 12.00.03; Нац. ун-т внутр. справ. Х., 2002. 16 с.

8. Реєстрація програм, баз даних та веб-сайтів. URL: http://patentresult.ua/ua/uslugi/ reyestratsiya-avtorskykh-prav/registratsiya-programm-i-baz-dannyh.html.

9. Базилевич В.Д., Ильин В.В. Метафизика экономики: монография. 2-е изд., испр. и доп. К.: Знання, 2010. 925 с.

10. Цибульов П.М. Основи інтелектуальної власності: навч. посібник. К.: Інститут інтелектуальної власності і права, 2003. 172 с.

\section{References:}

1. Hideyasu Sasaki. Intellectual Property Protection for Multimedia Information Technology. Retrieved from: https:/www.igi-global.com/book/intellectual-property-protection-multimediainformation/618. 
2. Yefremova, K.V. (2014). Do perspektyv pravovoho rehuliuvannia internet-pravovidnosyn: hospodarsko-pravovyi aspect [To the prospects of legal regulation of Internet legal relationships: the economic and legal aspect]. Pravo ta innovatsiine suspilstvo, no. 1, pp. 5-11.

3. Barabash, O.O. (2018). Zahalna kharakterystyka internet-pravovidnosy [General characteristics of online legal relationships]. IT-pravo: problemy i perspektyvy rozvytku $\mathrm{v}$ Ukraini: materialy konferentsii. Retrieved from: http://aphd.ua/publication-183/.

4. Buinytska, O.P. (2012). Informatsiini tekhnolohii ta tekhnichni zasoby navchannia: navch. posibnyk [Information technology and technical means of teaching: tutorial]. Kyiv: Tsentr uchbovoi literatury. [in Ukrainian].

5. Tomashevskyi, O.M., Tsehelyk, H.H., Viter, M.B., Dubuk, V.I. (2012). Informatsiini tekhnolohii ta modeliuvannia biznes-protsesiv: navch. posibnyk [Information technology and business process modeling: tutorial]. Kyiv: Tsentr uchbovoi literatury. [in Ukrainian].

6. Lytvynov, Ye.P. (2013). Pravovidnosyny v internet-pravi [Relationships in Internet Law]. Chasopys Kyivskoho universytetu prava, no. 3, pp. 145-149.

7. Selivanov, M.V. (2002). Zakhyst prava na komp'iuternu prohramu (avtorsko-pravovyi aspekt) [Protection of the right to a computer program (copyright law)] (PhD Thesis). Kharkiv: Kharkiv National University of Internal Affairs. [in Ukrainian].

8. Reiestratsiia prohram, baz danykh ta veb-saitiv [Registration of programs, databases and websites]. Retrieved from: http://patentresult.ua/ua/uslugi/reyestratsiya-avtorskykh-prav/ registratsiya-programm-i-baz-dannyh.html.

9. Bazilevich, V.D., Ilin, V.V. (2010). Metafizika ekonomiki: monografiia [Metaphysics of Economics: monograph]. 2nd ed., rev. and add. Kyiv: Znannia. [in Russian].

10. Tsybulov, P.M. (2003). Osnovy intelektualnoi vlasnosti: navch. posibnyk [Fundamentals of Intellectual Property: tutorial]. Kyiv: Instytut intelektualnoi vlasnosti i prava. [in Ukrainian].

\title{
ОГЛЯД ПРАВОВИХ АСПЕКТІВ ЩОДО ЗНИЖЕННЯ РИЗИКІВ ПОРУШЕННЯ ПРАВ ІНТЕЛЕКТУАЛЬНОЇ ВЛАСНОСТІ НА ІТ-ПРОДУКЦЮЮ
}

\author{
Наталія Рулікова, \\ доцент кафедри інтелектуальної власності та управління проектами \\ Національної металургійної академії України, \\ кандидат технічних наук

Інформаційні технології є об'єктом чесної та недобросовісної конкуренції як у світі загалом, так і в Україні зокрема, особливо через існування Інтернету. Тому необхідно регулювати відносини між виробниками та споживачами IT-технологій, пов'язаних із підприємницькою діяльністю, з обсягом цицррових продуктів. Це стало причиною необхідного впливу на правове регулювання споживчих відносин в Інтернеті. 
У статті проаналізовано питання вибору правових інструментів захисту прав на інформаційні продукти залежно від того, як вони далі використовуються для подальшої вигоди від їх використання та виключається можливість порушення прав недобросовісних конкурентів.

Метою статті є дослідження можливостей охорони прав на інформаційні технології як об'єкт інтелектуальної власності задля усунення ризиків порушення прав на цей об 'єкт. Для ії досягнення необхідно виконати такі завдання: розглянути процеси запобігання правопорушенням щзодо права інтелектуальної власності на об'єкти сфери IT-технологій за допомогою діючого правового інструментарію; проаналізувати складники інформачійних продуктів із метою визначення оптимальних шляхів їх правової охорони; надати аналіз недоліків охорони програмних продуктів тільки за допомогою авторського права; дослідити досвід країн - провідних виробників та користувачів інформачійних технологій для очінки можливості його застосування в межах правового поля українського законодавства. Методи: системний і порівняльний аналіз.

Результати. Надано визначення інформаційних технологій як специфічних технологій, які дають змогу за допомогою електронно-обчислювальних машин накопичувати, обробляти, зберігати та передавати будь-яку інформацію, отриману із зовнішнього середовища. IT-технології невідривно пов'язані із застосуванням програмно-технічних комплексів, що складаються з персональних комп'ютерів, мобільних телефонів, комунікаторів або робочих станцій із необхідним набором периферійних пристроїв, забезпечених необхідними програмними засобами. Такі об'єкти можуть охоронятися патентним правом. Виділені рекомендації щзодо запобігання ризикам правопорушень через ідентифікацію складників IT-технологій та визначення їх патентоспроможності.

Висновки. У статті проаналізовано питання щзодо вибору правових інструментів охорони прав на інформаційні продукти залежно від способу їх подальшого використання для отримання подальшої вигоди від їх використання та усунення можливості порушення прав із боку недобросовісних конкурентів. Рекомендовано

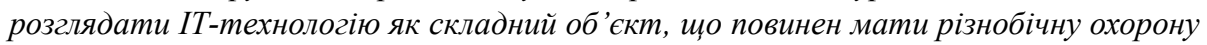
за допомогою авторського та патентного прав.

Охорона авторським правом не захищає розробників програмного забезпечення від посягань на їх IT-технологію, проте вона сприяє досягненню іншого результату покращення іміджу організації та отримання позитивного гудвілу. Для охорони програмних алгоритмів найбільш вигідною є охорона патентом на спосіб. А охорона IT-технології у вигляді комериійної таємнииі є доречною, коли вона стосується державної безпеки, військової техніки, є унікальною тощо.

Ключові слова: інформаційні технології, комп'ютерні програми, захист прав, об'єкти інтелектуальної власності. 